University of Nebraska - Lincoln

DigitalCommons@University of Nebraska - Lincoln

Biological Systems Engineering: Papers and

Publications

Biological Systems Engineering

$6-17-2020$

\title{
Retention of Swine Slurry Constituents in Soil and Crop Residue as Affected by Setback Distance
}

John E. Gilley

USDA-ARS, john.gilley@ars.usda.gov

Shannon L. Bartelt-Hunt

University of Nebraska - Lincoln, sbartelt2@unl.edu

Kent M. Eskridge

University of Nebraska - Lincoln, keskridge1@unl.edu

Xu Li

University of Nebraska-Lincoln, xuli@unl.edu

Amy M. Schmidt

University of Nebraska-Lincoln, aschmidt@unl.edu

See next page for additional authors

Follow this and additional works at: https://digitalcommons.unl.edu/biosysengfacpub

Part of the Bioresource and Agricultural Engineering Commons, Environmental Engineering Commons, and the Other Civil and Environmental Engineering Commons

Gilley, John E.; Bartelt-Hunt, Shannon L.; Eskridge, Kent M.; Li, Xu; Schmidt, Amy M.; and Snow, Daniel D., "Retention of Swine Slurry Constituents in Soil and Crop Residue as Affected by Setback Distance" (2020). Biological Systems Engineering: Papers and Publications. 676.

https://digitalcommons.unl.edu/biosysengfacpub/676

This Article is brought to you for free and open access by the Biological Systems Engineering at DigitalCommons@University of Nebraska - Lincoln. It has been accepted for inclusion in Biological Systems Engineering: Papers and Publications by an authorized administrator of DigitalCommons@University of Nebraska Lincoln. 


\section{Authors}

John E. Gilley, Shannon L. Bartelt-Hunt, Kent M. Eskridge, Xu Li, Amy M. Schmidt, and Daniel D. Snow 


\title{
Retention of Swine Slurry Constituents in Soil and Crop Residue as Affected by Setback Distance
}

\author{
John E. Gilley (D) - Shannon L. Bartelt-Hunt • Kent M. Eskridge • Xu Li • \\ Amy M. Schmidt • Daniel D. Snow
}

Received: 9 January 2020 / Accepted: 4 June 2020

(C) This is a U.S. government work and not under copyright protection in the U.S.; foreign copyright protection may apply 2020

\begin{abstract}
Setbacks are prescribed distances from surface waters within which manure application is not allowed. Little information is available concerning the retention of swine slurry constituents in soil and crop residue materials within setback areas. This study was conducted to measure the retention of selected constituents within a setback area following the upslope application of swine slurry and the introduction of simulated rainfall. The no-till cropland site had a slope gradient of $4.9 \%$ and a mean winter wheat residue cover of $7.73 \mathrm{Mg} \mathrm{ha}^{-1}$. Soil and vegetative samples were collected on $3.7 \mathrm{~m}$ wide by $23.2 \mathrm{~m}$ long plots with and without the addition of slurry. Slurry was added at the $0-4.9 \mathrm{~m}$ distance on selected plots, and simulated rainfall was then applied to the entire plot area during two separate
\end{abstract}

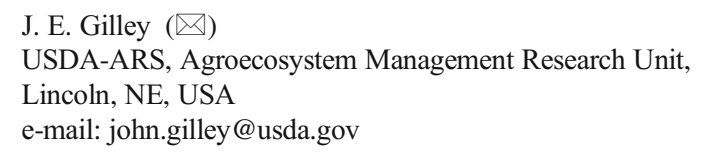
USA

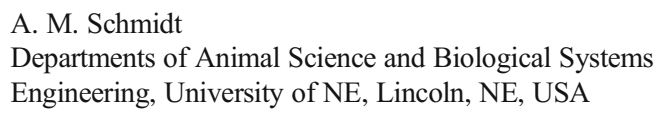

D. D. Snow

Nebraska Water Center, University of Nebraska, Lincoln, NE, USA events. Soil cores and vegetative samples were collected from each plot at distances of 2.44, 5.18, 7.92, 11.0, $14.0,17.1$, and $20.1 \mathrm{~m}$ from the upper plot border. The soil cores were separated into $0-10,10-20$, and 20 $30 \mathrm{~cm}$ depth increments. Significant increases in soil concentrations of chloride, nitrate, phosphorus, and zinc were found both within and downslope from the slurry application area. Residue materials located both within and downslope from the slurry application area contained significantly increased concentrations of boron, calcium, copper, magnesium, sulfur, and zinc. When estimating the downslope transport of constituents contained in swine slurry, contributions from runoff, soil, and residue should all be considered.

Keywords Crop residue - Infiltration - Land application . Manure runoff $\cdot$ Nutrients $\cdot$ Swine slurry

\section{Introduction}

\subsection{Background}

The suitability of swine slurry as a source of nutrients for plant production is influenced by the type of ration that is fed, swine housing system, method of manure collection, storage, and handling (Choudhary et al. 1996). The rate, timing, and method of swine manure application affect plant nutrient availability. The leaching of constituents following land application of swine slurry serves to reduce the potential for off-site surface water quality impacts. Soluble phosphorus 
Table 1 Background constituent concentrations for crop residue, irrigation water, soil, and slurry

\begin{tabular}{|c|c|c|c|c|c|c|}
\hline Material & Ammonium (mg kg $\left.{ }^{-1}\right)$ & Boron (mg kg ${ }^{-1}$ ) & Calcium (mg kg ${ }^{-1}$ ) & Chloride (mg kg${ }^{-1}$ ) & Copper $\left(\mathrm{mg} \mathrm{kg}^{-1}\right)$ & $\mathrm{EC}\left(\mathrm{dS} \mathrm{m} \mathrm{m}^{-1}\right)$ \\
\hline Crop residue & & $4.35(1.36)$ & $7160(1380)$ & $790(330)$ & $7.31(1.83)$ & \\
\hline Irrigation water & $<0.1(<0.1)$ & $0.06(0.008)$ & $83(1.37)$ & $4(2.40)$ & $<0.01(<0.01)$ & $0.72(0.023)$ \\
\hline Soil $(0-10 \mathrm{~cm})$ & & $2.02(1.87)$ & $3780(810)$ & $2.77(1.47)$ & $1.10(0.36)$ & $0.498(0.345)$ \\
\hline Slurry & $2980(138)$ & $4.40(0.19)$ & $2220(191)$ & & $69.1(15.9)$ & $25.9(2.81)$ \\
\hline
\end{tabular}

Standard deviation values are shown in parentheses

concentrations have been found to diminish by repeated rainfall events (Kleinman and Sharpley 2003) and the time that has expired to the first runoff event (Smith et al. 2007). The present study was conducted to measure changes in selected chemical constituents in soil and crop residue located both within and downslope from a slurry application area following the introduction of simulated rainfall.

An area where manure is not applied but crops continue to be grown is a setback. Increasing the distance that overland flow must travel to reach surface water bodies reduces the transport of contaminants in runoff. The application of manure no closer than $30.5 \mathrm{~m}$ to any down gradient surface water, open tile intake structure, sinkhole, agricultural well head, or other conduit to surface waters is a US Environmental Protection Agency (EPA) requirement for concentrated animal feeding operations (EPA 2012).

This manuscript contains additional information generated during an investigation reported by Gilley et al. (2017). Gilley et al. (2017) examined the effects of setback distance and runoff rate on concentrations of selected constituents in runoff following the land application of swine slurry to a no-till cropland site in southeast Nebraska. An initial set of rainfall simulation tests was completed to identify background concentrations of runoff constituents. Swine slurry was then applied to the upper $4.9 \mathrm{~m}$ of the slurry application plots, and additional rainfall simulation tests were conducted. A first- order exponential decay function was used to estimate the effects of setback distance on concentrations of selected constituents. A setback distance of $12.2 \mathrm{~m}$ reduced runoff concentrations of dissolved phosphorus, $\mathrm{NH}_{4}-\mathrm{N}$, total $\mathrm{N}$, boron, chloride, manganese, potassium, sulfate, zinc, electrical conductivity, and $\mathrm{pH}$ to background values like those measured for the no-slurry condition.

\subsection{Swine Slurry Constituents in Soil}

Several studies have been conducted which examined soil characteristics following land application of swine manure to sites on which corn was grown. Evans et al. (1977) found that the addition of swine manure in excess of crop nutrient requirements increased concentrations of nitrate, phosphorus, potassium, and sodium within soil. Concentrations of nitrate, phosphorus, and sodium in soil were also determined to increase with greater swine manure application rates (Sutton et al. 1978). Sutton et al. (1982) reported that concentrations of soil ammonium, nitrate, phosphorus, and potassium were greater on plots where manure was injected rather than surface applied. Increasing dietary salt levels resulted in larger sodium levels in manure and sodium loading of soil (Sutton et al. 1984).

The effects of land application of swine manure on soil properties of pasture areas have also been investigated. Reddy et al. (1980) found that the addition of

Table 2 Background constituent concentrations for crop residue, irrigation water, soil, and slurry

\begin{tabular}{|c|c|c|c|c|c|c|}
\hline Material & Iron $\left(\mathrm{mg} \mathrm{kg}^{-1}\right)$ & Magnesium (mg kg $\left.{ }^{-1}\right)$ & Manganese $\left(\mathrm{mg} \mathrm{kg}^{-1}\right)$ & Nitrate $\left(\mathrm{mg} \mathrm{kg}^{-1}\right)$ & $\mathrm{pH}$ & Potassium $\left(\mathrm{mg} \mathrm{kg}^{-1}\right)$ \\
\hline Crop residue & $3720(2160)$ & $1470(391)$ & $167(94.9)$ & & & $2090(591)$ \\
\hline Irrigation water & $<0.01(<0.01)$ & $21(1.17)$ & $0.02(0.005)$ & $14.2(0.55)$ & $7.50(0.055)$ & $3(0.00)$ \\
\hline Soil $(0-10 \mathrm{~cm})$ & $26.5(8.6)$ & $502(162)$ & $12.5(3.4)$ & $9.18(6.82)$ & $6.75(0.32)$ & $390(90)$ \\
\hline Slurry & $202(31.7)$ & $1950(308)$ & $43.4(9.20)$ & $2.43(0.455)$ & $7.81(0.19)$ & $2640(90.7)$ \\
\hline
\end{tabular}

Standard deviation values are shown in parentheses 
Table 3 Background constituent concentrations for crop residue, irrigation water, soil, and slurry

\begin{tabular}{|c|c|c|c|c|c|}
\hline Material & Sodium (mg kg $\left.{ }^{-1}\right)$ & Sulfur (mg kg $\left.{ }^{-1}\right)$ & Total N (mg kg $\left.{ }^{-1}\right)$ & Total P (mg kg $\left.{ }^{-1}\right)$ & Zinc $\left(\mathrm{mg} \mathrm{kg}^{-1}\right)$ \\
\hline Crop residue & & 938 (174) & $9900(2060)$ & $1110(201)$ & $32.4(6.5)$ \\
\hline Irrigation water & $53(2.26)$ & $4.9(0.25)$ & $14.2(1.61)$ & $0.39(0.39)$ & $0.05(0.035)$ \\
\hline Soil $(0-10 \mathrm{~cm})$ & $24.2(24.6)$ & $69.9(67.8)$ & $9.18(6.82)$ & $22.2(13.7)$ & $0.94(0.36)$ \\
\hline Slurry & $920(40.6)$ & $588(63.2)$ & $5520(643)$ & $2890(1070)$ & $131(15.2)$ \\
\hline
\end{tabular}

Standard deviation values are shown in parentheses

swine lagoon effluent to pasture areas increased soil phosphorus. Increased concentrations of soil nitrate, phosphorus, potassium, and sodium were found following the introduction of swine manure to a soil on which "Coastal" Bermuda grass was grown (King et al. 1985, 1990). Westerman et al. (1987) measured increases in soil nitrate, phosphorus, potassium, and sodium following the addition of swine manure to a site containing a temperate forage mixture.

\subsection{Changes in Chemical Constituents Contained in Crop Residue}

Crop residues may also influence nutrient concentrations in runoff. Schreiber (1985) determined that wheat residues subjected to rainfall were a substantial source of soluble nutrients in agricultural runoff. Concentrations and quantities of ammonium, nitrate, organic carbon, and phosphorus released from wheat straw as a function of rainfall intensity were identified by Schreiber and McDowell (1985). Less than $1 \%$ of the total $\mathrm{N}$ and 8 to $14 \%$ of the total phosphorus in the wheat residue were leached for the given experimental conditions. Cermak et al. (2004) found that wheat residue adsorbed ammonia and phosphorus with an increase in adsorption generally resulting from greater residue immersion period. Wheat stalk residues

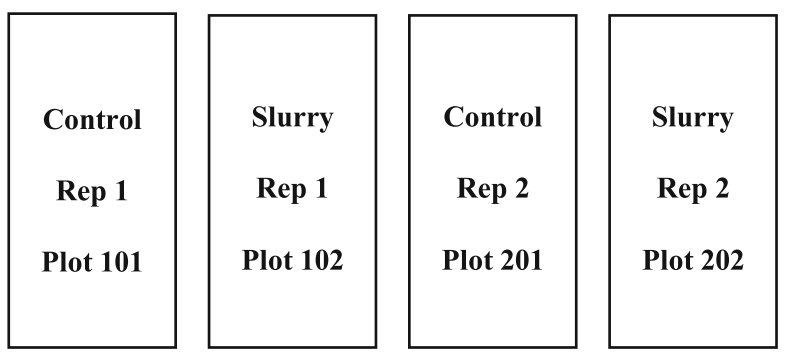

Fig. 1 Schematic showing plot layout for the experimental plots on which soil and vegetative samples were collected. Both the control and slurry plots were $23.2 \mathrm{~m}$ long. Neither rainfall nor slurry was applied to the control plots. Rainfall simulation tests were found by Gilley et al. (2009) to adsorb nitrate and ammonia and release phosphorus. The quantity of ammonia adsorbed by wheat stalk residue increased as the concentration of ammonia in solution became greater. Lozier et al. (2017) reported that cover crops such as winter wheat have the potential to release substantial quantities of phosphorus during the nongrowing season. Loads of dissolved reactive phosphorus $\left(0.165-0.245 \mathrm{~kg} \mathrm{ha}^{-1}\right)$ and total phosphorus $\left(0.295-0.360 \mathrm{~kg} \mathrm{ha}^{-1}\right)$ leaving the fields were small in comparison with phosphorus pools in cover crops suggesting that much of the phosphorus released from vegetation was retained within the field.

\section{Materials and Methods}

\subsection{Study Site Characteristics}

This field study was conducted at the University of Nebraska Rogers Memorial Farm located $18 \mathrm{~km}$ east of Lincoln, NE, USA. The study site had been cropped using a long-term no-till management system with controlled wheel traffic which included corn, grain sorghum, soybeans, and winter wheat. Winter wheat was harvested from the study location in July 2015. Glyphosate was applied as needed

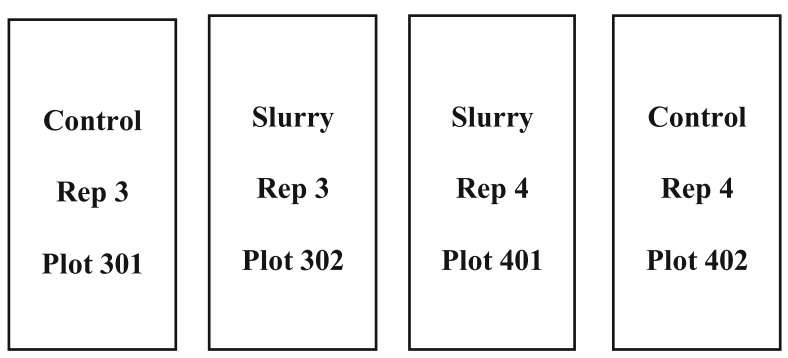

were first conducted without swine slurry application on the slurry plots. Slurry was then added to the top $4.9 \mathrm{~m}$ of the slurry plots, and additional rainfall simulation tests were conducted 
Fig. 2 Schematic showing crop residue and soil sample collection locations. The small circles show the sites where soil cores were obtained. At a given distance, crop residue was obtained in the area located between the three soil sample collection sites
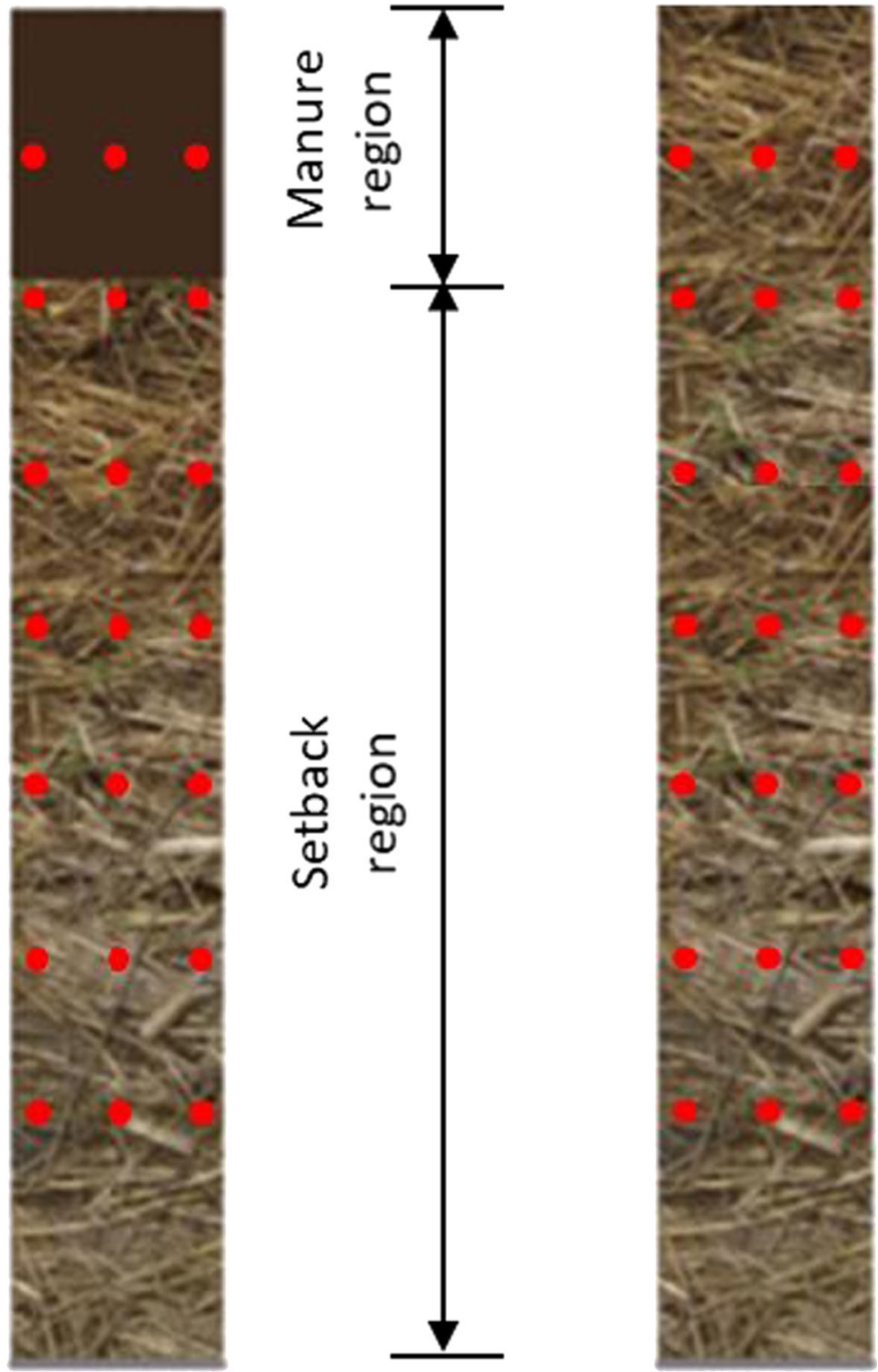

following harvest to control weed growth. The amount of vegetative material at the study site at the time of the field tests was $7.73 \mathrm{Mg} \mathrm{ha}^{-1}$.

The soil at the site developed in loess under prairie vegetation and is considered a benchmark soil. Using procedures for soil particle size determination reported by Kettler et al. (2001), the Aksarben clay loam (fine, smectitic, mesic Typic Argiudoll) contained 22\% sand,
$44 \%$ silt, and $34 \%$ clay. The hydraulic conductivity of the Aksarben soil is moderately low and the soil belongs to hydrologic group C. Infiltration excess overland flow is thought to be the primary runoff generating process at this site (Buchanan et al. 2018).

Mean concentrations of Bray and Kurtz No. $1 \mathrm{P}$ (Bray and Kurtz 1945), water-soluble P (Murphy and Riley 1962), and $\mathrm{NO}_{3}-\mathrm{N}$ at the $0-10 \mathrm{~cm}$ depth measured 
Table 4 Effects of slurry application, soil depth, and distance on soil characteristics

\begin{tabular}{|c|c|c|c|c|c|}
\hline & Boron & Calcium & Chloride & Copper & $\mathrm{EC}$ \\
\hline \multicolumn{6}{|l|}{ Slurry application } \\
\hline No slurry & $1.96(2.06)$ & $3490(767)$ & $2.42(1.36)$ & $1.26(0.38)$ & $0.467(0.389)$ \\
\hline Slurry & $1.62(1.69)$ & $3770(518)$ & $4.17(6.22)$ & $1.34(0.21)$ & $0.435(0.303)$ \\
\hline \multicolumn{6}{|l|}{ Depth (cm) } \\
\hline $0-10$ & $1.76(1.88)$ & 3970a (669) & $4.78 \mathrm{a}(4.56)$ & $1.19 b(0.31)$ & $0.519(0.347)$ \\
\hline $10-20$ & $1.68(2.05)$ & $3460 b(607)$ & $2.53 b(2.12)$ & $1.39 \mathrm{a}(0.29)$ & $0.414(0.364)$ \\
\hline $20-30$ & $1.92(2.16)$ & $3460 b(547)$ & $2.59 \mathrm{~b}(1.81)$ & $1.31 \mathrm{a}(0.27)$ & $0.420(0.349)$ \\
\hline \multicolumn{6}{|l|}{ Distance (m) } \\
\hline 2.44 & $2.01(1.78)$ & $3390(604)$ & 7.38a (10.7) & $1.36(0.37)$ & $0.510(0.370)$ \\
\hline 5.18 & $2.08(2.13)$ & $3600(724)$ & $3.15 b(2.20)$ & $1.28(0.36)$ & $0.524(0.388)$ \\
\hline 7.92 & $2.32(2.19)$ & $3730(723)$ & $2.94 \mathrm{~b}(1.81)$ & $1.29(0.31)$ & $0.470(0.354)$ \\
\hline 11.0 & $2.78(2.17)$ & $3730(729)$ & $2.76 \mathrm{~b}(1.40)$ & $1.24(0.28)$ & $0.605(0.382)$ \\
\hline 14.0 & $0.786(0.588)$ & $3660(702)$ & $2.40 \mathrm{~b}(1.76)$ & $1.30(0.29)$ & $0.305(0.165)$ \\
\hline 17.1 & $1.31(1.62)$ & $3710(562)$ & $2.35 b(1.73)$ & $1.31(0.29)$ & $0.367(0.327)$ \\
\hline 20.1 & $1.23(1.48)$ & $3570(626)$ & $2.10 \mathrm{~b}(0.79)$ & $1.31(0.28)$ & $0.375(0.327)$ \\
\hline \multicolumn{6}{|l|}{ ANOVA $(p>F)$} \\
\hline Slurry & 0.52 & 0.55 & 0.14 & 0.70 & 0.82 \\
\hline Depth & 0.74 & $<0.01$ & 0.02 & 0.04 & 0.19 \\
\hline Distance & 0.11 & 0.12 & $<0.01$ & 0.84 & 0.06 \\
\hline Slurry $\times$ depth & 0.75 & 0.38 & 0.06 & 0.38 & 0.62 \\
\hline Slurry $\times$ distance & 0.02 & 0.61 & $<0.01$ & 0.59 & 0.07 \\
\hline Depth $\times$ distance & 0.81 & 0.18 & $<0.01$ & 0.30 & 0.45 \\
\hline Slurry $\times$ depth $\times$ distance & 0.70 & 0.60 & $<0.01$ & 0.42 & 0.58 \\
\hline
\end{tabular}

All values are in $\mathrm{mg} \mathrm{kg}^{-1}$ except for $\mathrm{EC}\left(\mathrm{dS} \mathrm{m}^{-1}\right)$ and $\mathrm{pH}$. Within the same column, values followed by different letters are significantly different at the 0.05 probability level based on the LSD test. Standard deviation values are shown in parentheses

with a flow injection analyzer using spectrophotometry (SEAL AutoAnalyzer 3, SEAL Analytical Inc., Mequon, WI) were 17.9, 1.7, and $9.4 \mathrm{mg} \mathrm{kg}^{-1}$, respectively. The study site had a mean slope gradient of $4.9 \%$, electrical conductivity (EC) of $0.51 \mathrm{dS} \mathrm{m}^{-1}$, and a $\mathrm{pH}$ of 6.7 (Klute 1986). Using laboratory procedures developed by Nelson and Sommers (1996), the organic matter and total carbon content of the soil at the $0-10 \mathrm{~cm}$ depth were 38 and $22 \mathrm{~g} \mathrm{~kg}^{-1}$, respectively, which are relatively high for cropland sites in this region. The background concentrations for other constituents contained in the soil at the $0-10 \mathrm{~cm}$ depth, determined on a dry weight basis, are identified in Tables 1, 2, and 3 .

\subsection{Experimental Design}

The experimental plots were established using a randomized design with four replications (Fig. 1). Each of the plots was $3.7 \mathrm{~m}$ wide and $23.2 \mathrm{~m}$ long. Soil and vegetative samples were collected on plots with and without slurry over an 8 -week period extending from June 8 to August 3 , 2016. These dates were selected because students were available during their summer break to assist with field activities. Slurry was added at the $0-4.9 \mathrm{~m}$ distance on the manure application plots. The concentration of chemical constituents was reported on a dry weight basis on both the slurry and no slurry treatments.

\subsection{Slurry Collection and Application}

Slurry was obtained a few hours prior to field application from a deep pit on a commercial wean-to-finish swine operation in southeast Nebraska. The slurry was transported in $20 \mathrm{~L}$ plastic buckets until it was land applied. Two subsamples of the slurry were collected and composited from separate plastic buckets for 
Table 5 Effects of slurry application, soil depth, and distance on soil characteristics

\begin{tabular}{|c|c|c|c|c|c|c|}
\hline & Iron & Magnesium & Manganese & Nitrate & Phosphorus (Bray-1) & Phosphorus (Mehlich-3) \\
\hline \multicolumn{7}{|l|}{ Slurry application } \\
\hline No slurry & $36.5(14.7)$ & 644 (239) & $15.1(6.4)$ & $5.03(5.19)$ & $8.97(9.48)$ & $10.4(12.2)$ \\
\hline Slurry & $32.2(13.5)$ & 754 (229) & $13.4(3.63)$ & $7.1(6.94)$ & $8.16(9.23)$ & $11.4(17.4)$ \\
\hline \multicolumn{7}{|l|}{ Depth $(\mathrm{cm})$} \\
\hline $0-10$ & $25.6 \mathrm{~b}(14.2)$ & $553 b(241)$ & $12.1 \mathrm{~b}(5.23)$ & $11.3 \mathrm{a}(6.17)$ & $17.6 \mathrm{a}(9.29)$ & $24.3 \mathrm{a}(14.9)$ \\
\hline $10-20$ & 44.9 a (14.8) & 698b (244) & $17.1 \mathrm{a}(6.2)$ & $3.96 b(1.47)$ & $4.06 \mathrm{~b}(2.40)$ & $4.38 b(2.92)$ \\
\hline $20-30$ & $32.5 b(12.3)$ & $846 a(228)$ & $13.5 \mathrm{ab}(5.33)$ & $2.96 b(1.44)$ & $4.02 \mathrm{~b}(2.69)$ & $4.06 \mathrm{~b}(3.13)$ \\
\hline \multicolumn{7}{|l|}{ Distance (m) } \\
\hline 2.44 & $34.7(13.6)$ & $668(225)$ & $14.3(4.9)$ & $8.83 a(11.6)$ & $12.5 \mathrm{a}(14.2)$ & 21.0a (29.2) \\
\hline 5.18 & $34.6(14.4)$ & 667 (229) & $15.5(6.0)$ & $5.15 b(3.53)$ & $9.74 \mathrm{ab}(13.5)$ & $11.7 \mathrm{~b}(15.9)$ \\
\hline 7.92 & $32.6(12.4)$ & 724 (237) & $14(4.2)$ & $5.88 b(7.11)$ & $7.58 b(6.60)$ & $8.29 b c(8.16)$ \\
\hline 11.0 & $32.6(13.2)$ & $716(254)$ & $14.2(5.7)$ & $5.16 \mathrm{~b}(4.10)$ & $8.04 b(6.72)$ & $9.84 \mathrm{~b}(9.20)$ \\
\hline 14.0 & $35.3(15.9)$ & $703(250)$ & $14(5.7)$ & $5.88 \mathrm{~b}(4.00)$ & $7.05 b(6.77)$ & $7.80 \mathrm{~b}(8.55)$ \\
\hline 17.1 & $35.1(14.2)$ & $724(254)$ & $13.6(4.7)$ & $5.33 b(4.30)$ & $7.73 b(7.07)$ & $8.88 b(8.72)$ \\
\hline 20.1 & $35.4(16.7)$ & $690(259)$ & $14.2(5.5)$ & $6.26 b(4.34)$ & $7.29 \mathrm{~b}(6.00)$ & $8.92 b(9.11)$ \\
\hline \multicolumn{7}{|l|}{ ANOVA $(p>F)$} \\
\hline Slurry & 0.44 & 0.48 & 0.5 & 0.31 & 0.68 & 0.71 \\
\hline Depth & $<0.01$ & $<0.01$ & 0.01 & $<0.01$ & $<0.01$ & $<0.01$ \\
\hline Distance & 0.84 & 0.65 & 0.53 & 0.03 & 0.02 & $<0.01$ \\
\hline Slurry $\times$ depth & 0.53 & 0.38 & 0.43 & 0.49 & 0.87 & 0.65 \\
\hline Slurry $\times$ distance & 0.81 & 0.18 & 0.47 & $<0.01$ & $<0.01$ & $<0.01$ \\
\hline Depth $\times$ distance & 0.92 & 0.55 & 0.57 & $<0.01$ & 0.08 & $<0.01$ \\
\hline Slurry $\times$ depth $\times$ distance & 0.72 & 0.57 & 0.32 & $<0.01$ & $<0.01$ & $<0.01$ \\
\hline
\end{tabular}

All values are in $\mathrm{mg} \mathrm{kg}^{-1}$ except for EC $\left(\mathrm{dS} \mathrm{m}^{-1}\right)$ and $\mathrm{pH}$. Within the same column, values followed by different letters are significantly different at the 0.05 probability level based on the LSD test. Standard deviation values are shown in parentheses

chemical and physical analyses. The subsamples were shipped to a commercial laboratory the same day they were collected. The concentrations of constituents in the slurry, which had a mean dry matter content of $5.35 \%$, are shown in Tables 1, 2, and 3. Mineral elements commonly added to swine diets to enhance growth performance include chloride, copper, iron, manganese, sodium, and zinc (NRC 1998; Hill and Spears 2001; Patience and Zijlstra 2001).

Slurry was applied at a rate required to meet the annual nitrogen requirement for corn $\left(151 \mathrm{~kg} \mathrm{~N} \mathrm{ha}^{-1}\right.$ year $^{-1}$ for an expected yield of $9.4 \mathrm{Mg} \mathrm{ha}^{-1}$ ). When calculating slurry application rate, it was assumed that the nitrogen availability from the swine slurry was $70 \%$ of the total amount of measured nitrogen (Gilbertson et al. 1979). The amount of slurry required to meet crop nutrient requirements was calculated, and individual plastic buckets were weighed until the desired quantity was obtained. The plastic buckets were then transported and placed uniformly outside the application area. The slurry was then carefully applied by hand to the soil surface and was not incorporated following application.

\subsection{Rainfall Simulation Procedures}

A portable rainfall simulator designed by Schulz and Yevjevich (1970) was used to apply rainfall at a rate of approximately $52 \mathrm{~mm} \mathrm{~h}^{-1}$ to the entire plot area. The $52 \mathrm{~mm} \mathrm{~h}^{-1}$ intensity resulted when the recommended sprinkler head spacing and design operating pressure were utilized. The "sprinkler head grid system" used $3.0 \mathrm{~m}$ sections of $10 \mathrm{~cm}$ diameter irrigation pipe on which $2 \mathrm{~cm}$ diameter risers were mounted. Sprinkler heads were located on the top of the risers which also contained a globe valve, a flow control valve, and a screen. Placement of the selected sprinkler heads at $3.0 \mathrm{~m}$ intervals along supply lines separated by $5.2 \mathrm{~m}$ was found by Schulz and 
Table 6 Effects of slurry application, soil depth, and distance on soil characteristics

\begin{tabular}{|c|c|c|c|c|c|c|}
\hline & Phosphorus (water-soluble) & $\mathrm{pH}$ & Potassium & Sodium & Sulfur & Zinc \\
\hline \multicolumn{7}{|l|}{ Slurry application } \\
\hline No slurry & $0.97(0.71)$ & $6.22(0.56)$ & $264(112)$ & $29.3(30.1)$ & $80.8(115)$ & $0.62(0.36)$ \\
\hline Slurry & $1.04(0.85)$ & $6.51(0.42)$ & $279(99.1)$ & $34.9(27.8)$ & $60(82.2)$ & $0.71(0.51)$ \\
\hline \multicolumn{7}{|l|}{ Depth (cm) } \\
\hline $0-10$ & $1.65 \mathrm{a}(0.78)$ & $6.91 \mathrm{a}(0.52)$ & 392a (105) & $31.2(28.9)$ & $64.1(99.7)$ & $1.09 \mathrm{a}(0.44)$ \\
\hline $10-20$ & $0.690 \mathrm{~b}(0.332)$ & $6.07 b(0.48)$ & $212 \mathrm{~b}(50)$ & $29.8(36.7)$ & $71.7(112)$ & $0.497 b(0.17)$ \\
\hline $20-30$ & $0.690 \mathrm{~b}(0.318)$ & $6.13 b(0.46)$ & $210 b(47)$ & $35.3(35.6)$ & $75.3(113)$ & $0.403 b(0.20)$ \\
\hline \multicolumn{7}{|l|}{ Distance (m) } \\
\hline 2.44 & $1.38(1.42)$ & $6.17 b(0.47)$ & $265(105)$ & $31(28.5)$ & $89(120)$ & $0.851 \mathrm{a}(0.716)$ \\
\hline 5.18 & $1.1(0.85)$ & $6.30 \mathrm{a}(0.55)$ & $265(97)$ & $31.8(26.9)$ & $91(120)$ & $0.730 \mathrm{ab}(0.408)$ \\
\hline 7.92 & $0.968(0.43)$ & $6.48 \mathrm{a}(0.43)$ & $273(108)$ & $35.5(33.7)$ & $92.2(114)$ & $0.670 \mathrm{~b}(0.415)$ \\
\hline 11.0 & $0.765(0.41)$ & $6.40 \mathrm{a}(0.54)$ & $264(104)$ & $38.3(25.5)$ & $105(105)$ & $0.617 b(0.339)$ \\
\hline 14.0 & $1.02(0.81)$ & $6.45 \mathrm{a}(0.57)$ & $274(104)$ & $21.1(13.3)$ & $19.6(20.0)$ & $0.592 b(0.360)$ \\
\hline 17.1 & $0.924(0.53)$ & $6.42 \mathrm{a}(0.55)$ & $288(124)$ & $33.5(38.2)$ & $45.3(72.9)$ & $0.605 b(0.376)$ \\
\hline 20.1 & $0.888(0.43)$ & $6.39 \mathrm{a}(0.56)$ & $271(102)$ & $33.4(30.6)$ & $50.3(86.3)$ & $0.589 \mathrm{~b}(0.361)$ \\
\hline \multicolumn{7}{|l|}{$\operatorname{ANOVA}(p>F)$} \\
\hline Slurry & 0.55 & 0.13 & 0.71 & 0.65 & 0.50 & 0.45 \\
\hline Depth & $<0.01$ & $<0.01$ & $<0.01$ & 0.5 & 0.81 & $<0.01$ \\
\hline Distance & 0.08 & 0.02 & 0.63 & 0.61 & 0.06 & 0.03 \\
\hline Slurry $\times$ depth & 0.77 & 0.76 & 0.64 & 0.42 & 0.93 & 0.04 \\
\hline Slurry $\times$ distance & $<0.01$ & 0.21 & 0.81 & 0.07 & 0.11 & $<0.01$ \\
\hline Depth $\times$ distance & $<0.01$ & 0.65 & 0.87 & 0.73 & 0.55 & 0.03 \\
\hline Slurry $\times$ depth $\times$ distance & $<0.01$ & 0.62 & 0.47 & 0.51 & 0.63 & $<0.01$ \\
\hline
\end{tabular}

All values are in $\mathrm{mg} \mathrm{kg}^{-1}$ except for $\mathrm{EC}\left(\mathrm{dS} \mathrm{m}^{-1}\right)$ and $\mathrm{pH}$. Within the same column, values followed by different letters are significantly different at the 0.05 probability level based on the LSD test. Standard deviation values are shown in parentheses

Yevjevich (1970) to provide a relatively uniform rainfall distribution.

Water used in the rainfall simulation tests was obtained from an irrigation well. Replicated samples for background water quality analyses were collected from the outlet of the distribution system near the beginning and end of the field study. Variations in water quality characteristics among samples were minimal. The concentration of constituents contained in the irrigation water are identified in Tables 1, 2, and 3.

An initial rainfall simulation run without slurry addition occurred at the existing soil-water state and continued until steady-state runoff conditions had become established. The length of time required for steadystate runoff conditions to become established varied among plots depending upon the occurrence and quantity of natural precipitation. Steady-state runoff conditions were determined from visual observations of runoff quantities shown on stage recorder charts and are reported by Gilley et al. (2017). A mean overland flow rate of $22.91 \mathrm{~min}^{-1}$ was measured without the addition of inflow. A second rainfall simulation run was then conducted approximately $24 \mathrm{~h}$ later, and it also continued until steady-state runoff conditions were reestablished. The initial and second rainfall simulation runs provided baseline nutrient transport measurements.

Within a few minutes following completion of the second rainfall simulation run, additional field tests were conducted to identify the effects of varying runoff rates on nutrient transport. Inflow was added in three successive increments. A narrow mat made of green synthetic material often used as an outdoor carpet was placed on the soil surface beneath the inflow device to prevent scouring and distribute the flow more uniformly across the plot surface. Rainfall continued to be applied during the inflow tests.

Slurry was added to the upper $4.9 \mathrm{~m}$ of the paired plots on day 3 of the weekly test schedule. Additional 
Fig. 3 Chloride concentration as affected by soil depth and distance for the no-slurry and slurry experimental treatments. At a given depth, points followed by the same letter are not significantly different $(p \leq 0.05)$. Absence of letters indicates no significant differences in concentration values at a given depth
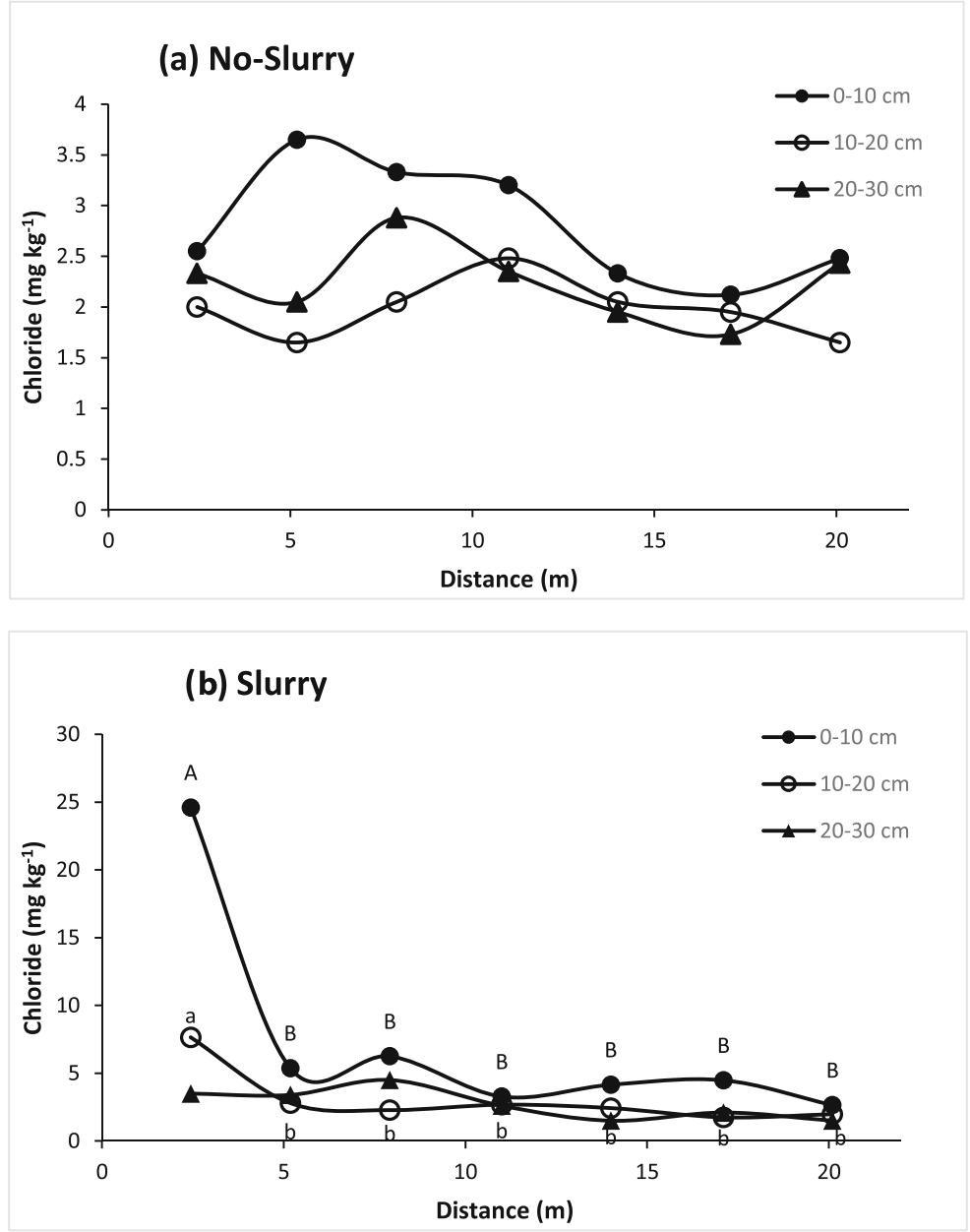

rainfall simulation tests occurred approximately 24 and $48 \mathrm{~h}$ after slurry addition (days 4 and 5 of the weekly routine) to provide nutrient transport measurements following slurry application. Runoff tests continued until establishment of steady-state runoff conditions.

Rain gauges were placed around the perimeter of each plot to measure total rainfall. The mean amount of rainfall applied during the initial run without and with slurry was $34 \mathrm{~mm}$ (standard deviation, $8 \mathrm{~mm}$ ) and $36 \mathrm{~mm}$ (standard deviation, $11 \mathrm{~mm}$ ), respectively. Mean rainfall applications of 82 (standard deviation, $6 \mathrm{~mm}$ ) and $71 \mathrm{~mm}$ (standard deviation, $9 \mathrm{~mm}$ ) was applied during run 2 and the inflow run on the no slurry and slurry treatments, respectively.

\subsection{Crop Residue Collection Procedures}

Crop residue was collected from each control and slurry application plot at distances of 2.44, 5.18, 7.92, 11.0,
14.0, 17.1, and $20.1 \mathrm{~m}$ from the upper plot border (Fig. 2). At each distance, residue samples were obtained at approximately 1.37 and $2.29 \mathrm{~m}$ transects from the right border (looking downslope) so as not to impact the surface where soil samples were later collected. Crop residue on the soil surface within a $0.69 \mathrm{~m}$ diameter circular frame was removed by hand and placed in paper bags. Individual samples were not composited. For the slurry application treatments, residue samples were collected 1 week following slurry application just before the soil samples were obtained.

Thus, two crop residue samples were collected at each distance, and a total of 14 samples were obtained on each plot. There were four replicates of each slurry and control treatment for a total of 8 plots and 112 residue samples. The residue samples were first dried in an oven and then ground. The mean mass of residue obtained from each sample location was 289 g dry weight. The samples were sent to a commercial 
Table 7 Slurry and rainfall application amounts and changes in soil, residue, and runoff quantities

\begin{tabular}{|c|c|c|c|c|c|c|}
\hline & Boron & Calcium & Chloride & Copper & Magnesium & Nitrate $^{[\mathrm{b}]}$ \\
\hline \multicolumn{7}{|l|}{ Slurry application amount } \\
\hline 0-4.9 m distance & $0.305^{[\mathrm{a}]}$ & 147 & & 4.59 & 141 & 0.087 \\
\hline \multicolumn{7}{|l|}{ Rainfall application amount } \\
\hline 0-4.9 $\mathrm{m}$ distance & 0.113 & 157 & 7.54 & 0.00 & 39.6 & 26.8 \\
\hline 4.9-23.2 $\mathrm{m}$ distance & 0.423 & 584 & 28.2 & 0.00 & 148 & 100 \\
\hline Total 0-23.2 $\mathrm{m}$ distance & 0.536 & 741 & 35.7 & 0.00 & 188 & 127 \\
\hline \multicolumn{7}{|l|}{ Soil constituent changes } \\
\hline \multicolumn{7}{|l|}{ 0-4.9 $\mathrm{m}$ distance } \\
\hline $0-10 \mathrm{~cm}$ soil depth & & & 22.4 & & & 22.6 \\
\hline 10-20 cm soil depth & & & 6.55 & & & 2.73 \\
\hline $20-30 \mathrm{~cm}$ soil depth & & & 1.18 & & & 2.22 \\
\hline Total - 0-30 cm soil depth & & & 30.1 & & & 27.6 \\
\hline \multicolumn{7}{|l|}{ 4.9-23.2 $\mathrm{m}$ distance } \\
\hline $0-10 \mathrm{~cm}$ soil depth & & & 3.70 & & & 2.76 \\
\hline 10-20 cm soil depth & & & 1.47 & & & 5.34 \\
\hline 20-30 cm soil depth & & & 0.35 & & & 3.98 \\
\hline Total $-0-30 \mathrm{~cm}$ soil depth & & & 5.52 & & & 12.1 \\
\hline Total 0-23.2 distance & & & 35.6 & & & 39.7 \\
\hline \multicolumn{7}{|l|}{ Residue constituent changes } \\
\hline 0-4.9 m distance & 0.072 & 45.0 & & 0.718 & 20.2 & \\
\hline 4.9-23.2 $\mathrm{m}$ distance & 0.126 & 130 & & 0.131 & 39.8 & \\
\hline 0-23.2 distance & 0.198 & 175 & & 0.849 & 60.0 & \\
\hline \multicolumn{7}{|l|}{ Runoff constituent ${ }^{[\mathrm{c}]}$} \\
\hline 0-4.9 $\mathrm{m}$ distance & 0.078 & 65.5 & 10.1 & 0.018 & 21.6 & 20.5 \\
\hline 4.9-23.2 $\mathrm{m}$ distance & 0.215 & 320 & 7.04 & 0.038 & 71.6 & 44.8 \\
\hline Total 0-23.2 distance & 0.293 & 386 & 17.1 & 0.056 & 93.2 & 65.3 \\
\hline
\end{tabular}

${ }^{[a]}$ All values are in grams

${ }^{[b]}$ The total nitrogen applied in slurry was $368 \mathrm{~g}$

${ }^{\text {[c] }}$ Values obtained from study by Gilley et al. (2017)

laboratory for analyses of boron, calcium, chloride, copper, iron, magnesium, manganese, nitrogen, phosphorus, potassium, sulfur, and zinc. The concentrations of constituents contained in the crop residue on the control plots are identified in Tables 1, 2, and 3.

\subsection{Soil Sample Collection Procedures}

After crop residue samples were obtained, a hydraulic mounted soil probe with a $3.18 \mathrm{~cm}$ diameter tip was used to collect $30 \mathrm{~cm}$ deep soil cores. Soil cores were obtained from each plot at distances of 2.44, 5.18, 7.92, $11.0,14.0,17.1$, and $20.1 \mathrm{~m}$ from the upper plot border at transects approximately $0.91,1.83$, and $2.74 \mathrm{~m}$ from the right border (looking downslope) (Fig. 2). The three soil cores from each distance were separated into 0-10, 10-20, and 20-30 cm depth increments and composited. Thus, for each distance, there were three composite soil samples or a total of 21 samples from each plot. There were four replicates of each slurry and no-slurry treatment for a total of 8 plots and 168 soil samples. Mean bulk densities at the study site for the $0-10,10-20$, and 20-30 cm depth increments were $1.44,1.62$, and $1.63 \mathrm{~g} \mathrm{~cm}^{-3}$, respectively.

Soil samples were collected 1 week following slurry addition on the slurry application treatments. The week delay following rainfall and slurry application allowed easier access to the plot area and simpler removal of soil 
Table 8 Slurry and rainfall constituent application amounts and changes in soil, residue, and runoff constituent quantities

\begin{tabular}{|c|c|c|c|c|}
\hline & Phosphorus & Phosphorus (Bray-1) & Sulfur & Zinc \\
\hline \multicolumn{5}{|l|}{ Slurry application amount } \\
\hline 0-4.9 m distance & $207^{[\mathrm{a}]}$ & & 39.6 & 8.77 \\
\hline \multicolumn{5}{|l|}{ Rainfall application amount } \\
\hline $0-4.9 \mathrm{~m}$ distance & 0.740 & & 9.24 & 0.09 \\
\hline 4.9-23.2 $\mathrm{m}$ distance & 2.75 & & 34.5 & 0.47 \\
\hline Total 0-23.2 $\mathrm{m}$ distance & 3.49 & & 43.7 & 0.56 \\
\hline \multicolumn{5}{|l|}{ Soil constituent changes } \\
\hline \multicolumn{5}{|l|}{$0-4.9 \mathrm{~m}$ distance } \\
\hline $0-10 \mathrm{~cm}$ soil depth & & 41.7 & & 1.32 \\
\hline $10-20 \mathrm{~cm}$ soil depth & & 6.78 & & 0.09 \\
\hline 20-30 cm soil depth & & 6.66 & & 0.12 \\
\hline Total $-0-30 \mathrm{~cm}$ soil depth & & 55.2 & & 1.53 \\
\hline \multicolumn{5}{|l|}{ 4.9-23.2 $\mathrm{m}$ distance } \\
\hline $0-10 \mathrm{~cm}$ soil depth & & 0.00 & & 0.26 \\
\hline $10-20 \mathrm{~cm}$ soil depth & & 0.00 & & 0.00 \\
\hline 20-30 cm soil depth & & 0.00 & & 0.00 \\
\hline Total - 0-30 cm soil depth & & 0.00 & & 0.26 \\
\hline Total 0-23.2 distance & & 55.2 & & 1.79 \\
\hline \multicolumn{5}{|l|}{ Residue constituent changes } \\
\hline $0-4.9 \mathrm{~m}$ distance & 26.3 & & 6.38 & 1.61 \\
\hline 4.9-23.2 $\mathrm{m}$ distance & 0.00 & & 4.24 & 0.94 \\
\hline $0-23.2$ distance & 26.3 & & 10.6 & 2.55 \\
\hline \multicolumn{5}{|l|}{ Runoff constituent ${ }^{[\mathrm{c}]}$} \\
\hline $0-4.9 \mathrm{~m}$ distance & 5.32 & & 14.9 & 0.04 \\
\hline 4.9-23.2 $\mathrm{m}$ distance & 0.94 & & 57.7 & 0.00 \\
\hline Total 0-23.2 distance & 6.26 & & 72.6 & 0.04 \\
\hline
\end{tabular}

${ }^{[a]}$ All values are in grams

[b] The total nitrogen applied in slurry was $368 \mathrm{~g}$

${ }^{[c]}$ Values obtained from study by Gilley et al. (2017)

from the sampling tube. The plot area was covered with plastic if natural rainfall was forecast, and the plastic was removed when there was no longer a threat of rainfall. The soil cores collected at the $2.44 \mathrm{~m}$ distance on the slurry application plots were obtained near the middle of the slurry application area which extended $4.9 \mathrm{~m}$ from the upper plot border. In comparison, the $5.18 \mathrm{~m}$ sample collection location was just below the bottom of the slurry application area.

The larger size clods in the composited soil samples were broken up by hand. The soil was later removed from the plastic bags and allowed to air dry. The air-dry soil samples were then ground and separated into two groups. One group of samples was analyzed in a USDA-ARS laboratory in Lincoln, NE, USA for Bray-1 P and water-soluble P. The other group of samples was sent to a commercial laboratory for analyses of boron, calcium, chloride, copper, EC, iron, magnesium, manganese, nitrate, Mehlich-3 phosphorus, $\mathrm{pH}$, potassium, sodium, sulfur, and zinc.

\subsection{Statistical Analyses}

The treatment factors used in the statistical analyses for soil were slurry application (slurry or no-slurry), soil depth $(0-10,10-20$, and $20-30 \mathrm{~cm})$, and distance $(2.44,5.18,7.92,11.0,14.0,17.1$, and $20.1 \mathrm{~m})$. Slurry application (slurry or no-slurry) and distance (2.44, $5.18,7.92,11.0,14.0,17.1$, and $20.1 \mathrm{~m}$ ) were the treatment factors employed in the statistical analyses for residue. Split-block analyses of variance were performed on both the soil and residue data using SAS (SAS Institute 2011). If a significant difference was 
Fig. 4 Nitrate concentration as affected by soil depth and distance for the no-slurry and slurry experimental treatments. At a given depth, points followed by the same letter are not significantly different $(p \leq 0.05)$. Absence of letters indicates no significant differences in concentration values at a given depth
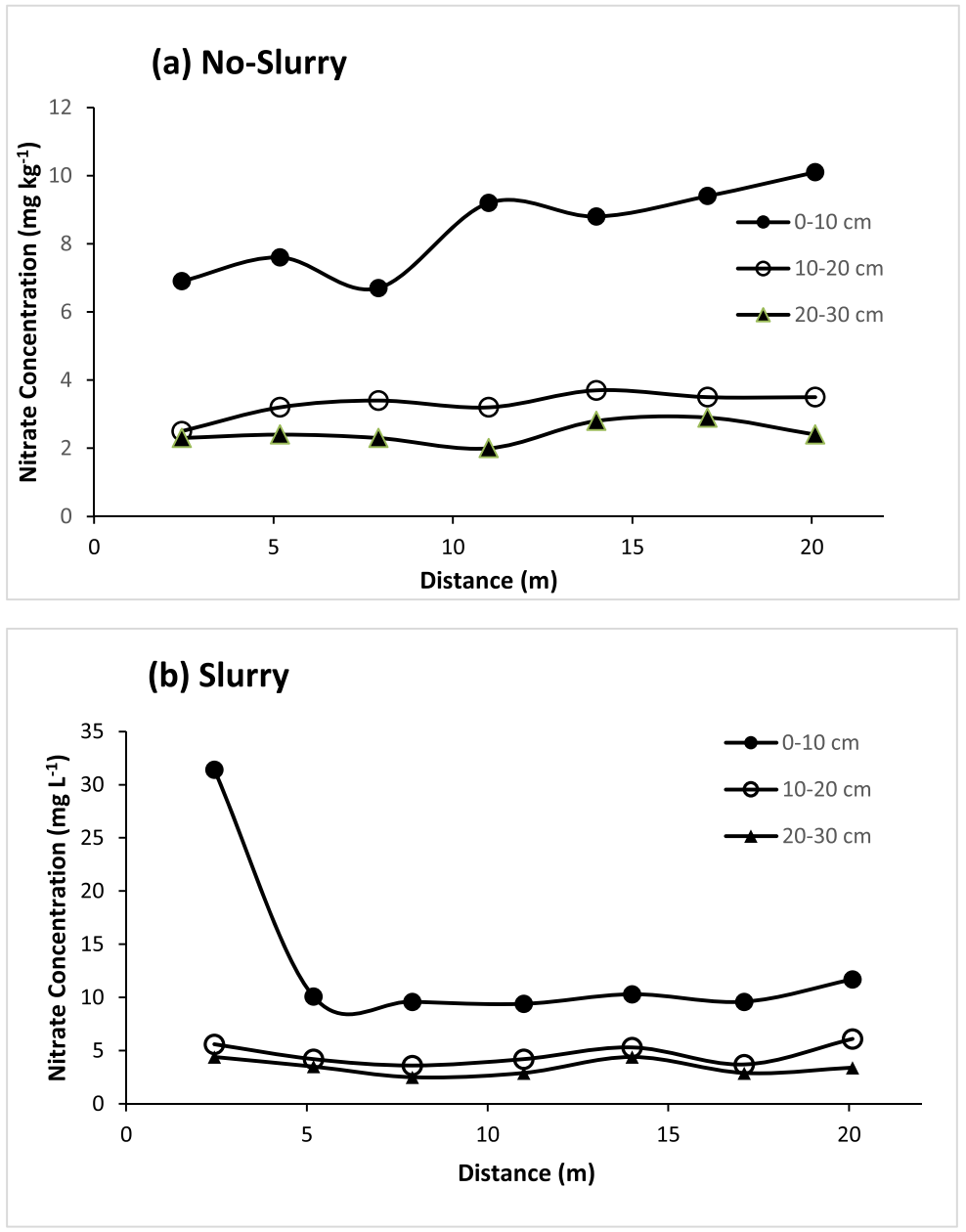

identified, the least significant difference (LSD) test was used to identify differences among experimental treatments. A probability level $p \leq 0.05$ was considered significant.

\section{Results and Discussion}

\subsection{Soil Analyses}

Analysis of variance indicated that there was no significant treatment or interactive effects for measurements of EC, sodium, or sulfur (Tables 4, 5, and 6). Soil depth significantly affected measurements of calcium, copper, iron, magnesium, manganese, $\mathrm{pH}$, and potassium. Values for calcium, $\mathrm{pH}$, and potassium were significantly larger at the $0-10 \mathrm{~cm}$ depth. In contrast, concentrations of copper, iron, magnesium, and manganese were largest at the $10-20$ or $20-30 \mathrm{~cm}$ depth increments.
Westerman et al. (1987) found that the application of swine slurry to a pasture planted to a temperate forage mixture had a minimal effect on soil concentrations of calcium, copper, magnesium, and manganese.

The $\mathrm{pH}$ value of 6.17 measured at the $2.44 \mathrm{~m}$ distance was significantly less than measurements obtained at the other locations (Table 6). Slurry with a relatively low $\mathrm{pH}$ value (larger quantity of $\mathrm{H}^{+}$ ions) infiltrated into the soil profile below the slurry application area causing smaller $\mathrm{pH}$ measurements. King et al. (1985) also noted a decrease in soil $\mathrm{pH}$ resulting from the application of swine lagoon effluent to "Coastal" Bermuda grass. No significant differences in $\mathrm{pH}$ measurements were found among distances varying from 5.18 to $20.1 \mathrm{~m}$.

An interaction between slurry application, soil depth, and distance was found for concentrations of chloride, nitrate, phosphorus constituents, and zinc (Tables 4, 5, and 6). 
Fig. 5 Bray-1 phosphorus concentration as affected by soil depth and distance for the noslurry and slurry experimental treatments. At a given depth, points followed by the same letter are not significantly different $(p \leq$ $0.05)$. Absence of letters indicates no significant differences in concentration values at a given depth (a) No-Slurry

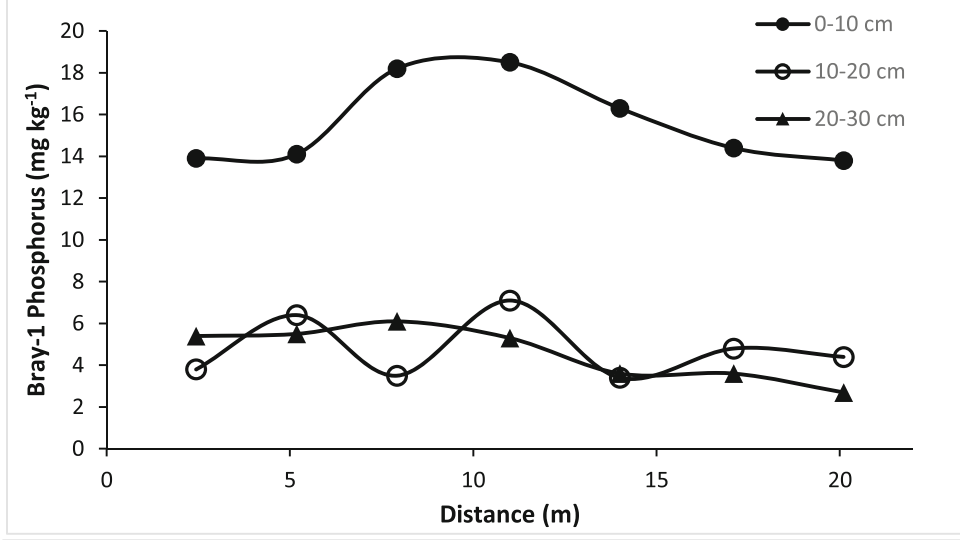

(b) Slurry

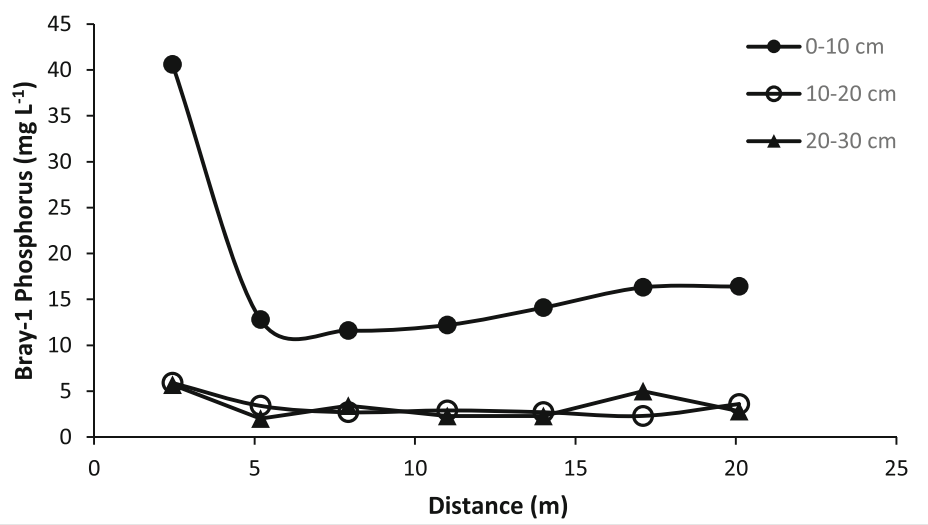

The largest chloride concentrations were found at the $0-10 \mathrm{~cm}$ soil depth on both the no-slurry and slurry treatments (Fig. 3). No significant differences in chloride concentration were found among sampling locations for a given soil depth on the no-slurry treatment. The chloride concentrations of 24.6 and $7.65 \mathrm{mg} \mathrm{kg}^{-1}$ measured at the $2.44 \mathrm{~m}$ distance at the $0-10$ and $10-$ $20 \mathrm{~cm}$ soil depths on the slurry treatment were significantly greater than the 5.38 and $2.80 \mathrm{mg} \mathrm{kg}^{-1}$ measured at the $5.18 \mathrm{~m}$ sampling location. (Soil constituent amounts were determined by multiplying the soil volume by bulk density and constituent concentration.) It was determined that 22.4 and $6.55 \mathrm{~g}$ of chloride had infiltrated into the $0-10$ and $10-20 \mathrm{~cm}$ soil depths within the slurry application area (Table 7). (Data obtained in the study reported by Gilley et al. (2017) were used to calculate the quantity of constituents transported in runoff shown in Tables 7 and 8.) The quantities of chloride that infiltrated into the $0-10$ and $10-20 \mathrm{~cm}$ soil depths on the plot area downslope from the slurry application region were 3.70 and $1.47 \mathrm{~g}$, respectively (Table 7).

The largest concentrations of nitrate were found at the $0-10 \mathrm{~cm}$ soil depth on both the no-slurry and slurry treatments (Fig. 4). No significant differences in soil nitrate measurements were found among sampling sites at the 10-20 and 20-30 cm depth increments on either the no-slurry or slurry treatments. The $31.4 \mathrm{mg} \mathrm{kg}^{-1}$ soil nitrate concentration measured at the $2.44 \mathrm{~m}$ distance for the $0-10 \mathrm{~cm}$ depth increment on the slurry treatment was significantly greater than values obtained at the other sampling locations. The total amount of nitrate that infiltrated into the slurry application and downslope areas were 27.6 and $12.1 \mathrm{~g}$, respectively (Table 7). Wienhold (2005) found that the nitrate content of soil increased following the application of swine slurry to plots on which sorghum were grown.

The largest concentrations of Bray-1 P were found at the $0-10 \mathrm{~cm}$ soil depth on both the no-slurry and slurry 
Fig. 6 Zinc concentration as affected by soil depth and distance for the no-slurry and slurry experimental treatments. At a given depth, points followed by the same letter are not significantly different $(p \leq 0.05)$. Absence of letters indicates no significant differences in concentration values at a given depth

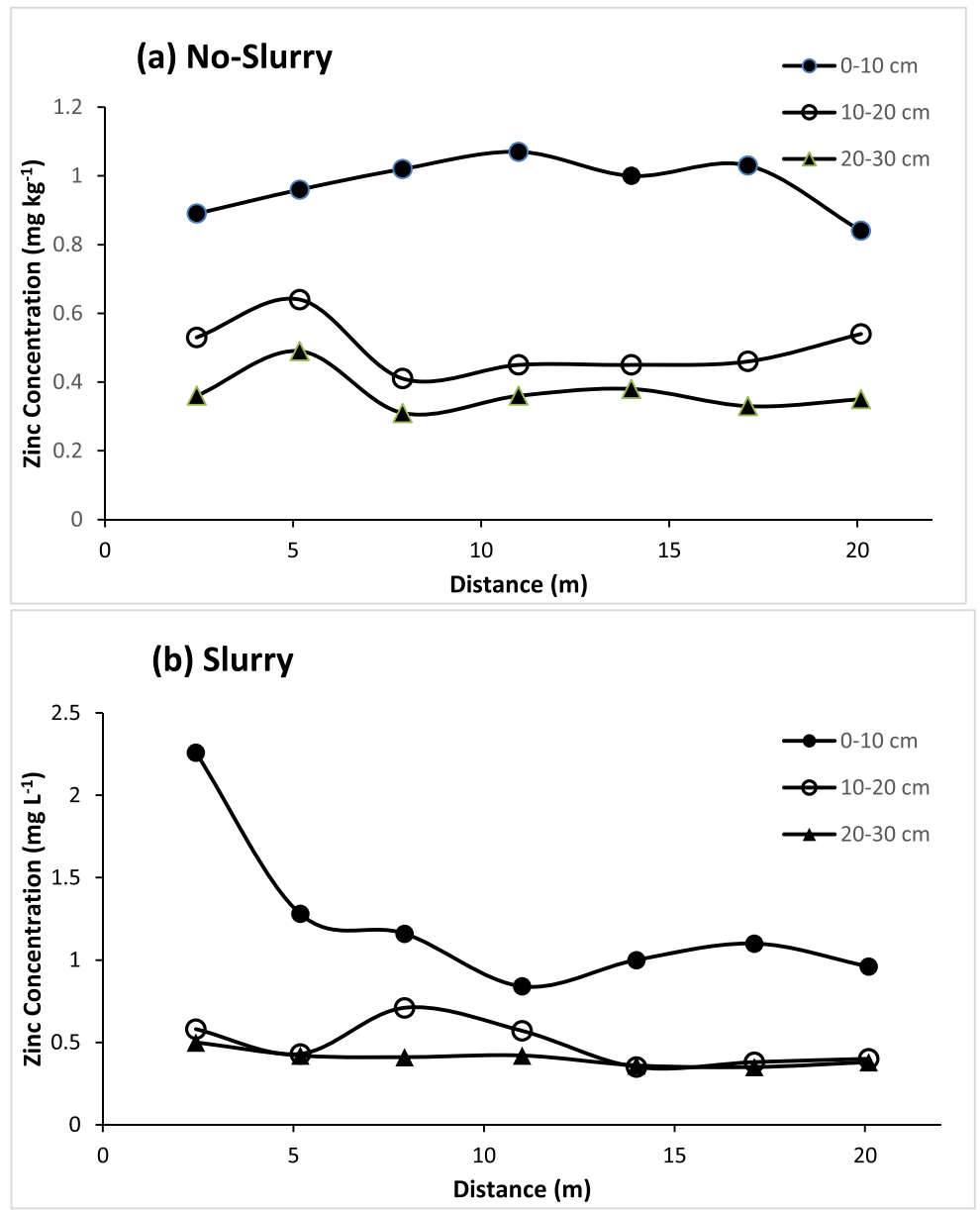

treatments (Fig. 5). No significant differences in Bray-1 P measurements were found among sampling sites at the 10-20 and 20-30 cm depth increments on either the noslurry or slurry treatments. The $40.6 \mathrm{mg} \mathrm{kg}^{-1}$ of Bray-1 P measured at the $2.44 \mathrm{~m}$ distance for the $0-10 \mathrm{~cm}$ depth increment on the slurry treatment was significantly greater than values obtained at the other distances. It was determined that $41.7 \mathrm{~g}$ of Bray-1 P infiltrated into the $0-10 \mathrm{~cm}$ depth increment within the slurry application area (Table 8). Bray-1P values did not change in the downslope region following slurry application. The experimental results shown for Bray-1 $\mathrm{P}$ are also characteristic of results obtained for Mehlich-3 P and water-soluble P. Reddy et al. (1980) found that continuous application of swine lagoon effluent for 3 years on a Cecil sandy loam increased soluble soil $\mathrm{P}$ and that no appreciable amount of $\mathrm{P}$ moved beyond the $30 \mathrm{~cm}$ depth. A significant increase in
Mehlich-3 $\mathrm{P}$ has been reported on soils following the long-term application of swine effluent (McLaughlin et al. 2010; Schlegel et al. 2015).

The largest concentrations of zinc were found at the $0-10 \mathrm{~cm}$ soil depth on both the no-slurry and slurry treatments (Fig. 6). No significant differences in measurements of zinc were found among sampling locations at the 10-20 and 20-30 cm depth increments on the no-slurry treatments. The $2.26 \mathrm{mg} \mathrm{kg}^{-1}$ of zinc measured on the slurry treatment at the $2.44 \mathrm{~m}$ distance for the $0-10 \mathrm{~cm}$ depth increment was significantly greater than values obtained at the other sampling sites. It was determined that $1.32 \mathrm{~g}$ of zinc infiltrated into the $0-10 \mathrm{~cm}$ depth on the slurry application area (Table 8). The long-term application of swine effluent was found to significantly increase extractable zinc in soil (Novak et al. 2004; Richards et al. 2011). 
Table 9 Effects of slurry application and distance on chemical characteristics of residue

\begin{tabular}{|c|c|c|c|c|c|c|}
\hline & Boron & Calcium & Chloride & Copper & Iron & Magnesium \\
\hline \multicolumn{7}{|l|}{ Slurry application } \\
\hline No slurry & $4.35 \mathrm{~b}(1.36)$ & $7160 \mathrm{~b}(1380)$ & $790(330)$ & $7.31 \mathrm{~b}(1.83)$ & $3720(2160)$ & $1470 \mathrm{~b}(390)$ \\
\hline Slurry & 7.91a (1.82) & 9780a (1580) & $720(280)$ & $16.9 \mathrm{a}(19.5)$ & $4930(2040)$ & $2340 \mathrm{a}(660)$ \\
\hline \multicolumn{7}{|l|}{ Distance (m) } \\
\hline 2.44 & $6.65(3.99)$ & $8260(2740)$ & $840(410)$ & $32.8 \mathrm{a}(31.8)$ & $2850(1200)$ & $2050(1060)$ \\
\hline 5.18 & $5.86(1.97)$ & $8270(2020)$ & $700(220)$ & $9.58 \mathrm{~b}(3.58)$ & $4670(2540)$ & $1950(770)$ \\
\hline 7.92 & $5.45(1.60)$ & $8160(1770)$ & $730(379)$ & $8.18 \mathrm{~b}(2.01)$ & $4350(2030)$ & $1810(490)$ \\
\hline 11.0 & $5.40(1.44)$ & $8450(1580)$ & $840(328)$ & $8.32 b(2.03)$ & $4500(2300)$ & $1800(482)$ \\
\hline 14.0 & $5.59(1.38)$ & $8370(1610)$ & $710(223)$ & $8.33 b(2.90)$ & $4460(1430)$ & $1770(516)$ \\
\hline 17.1 & $5.95(1.67)$ & $8680(1700)$ & $710(191)$ & $8.98 \mathrm{~b}(2.30)$ & $5130(2430)$ & $1940(625)$ \\
\hline 20.1 & $5.51(1.93)$ & $9080(2390)$ & $780(326)$ & $8.56 \mathrm{~b}(3.00)$ & $4320(2560)$ & $2030(769)$ \\
\hline \multicolumn{7}{|l|}{ ANOVA $(p>F)$} \\
\hline Slurry & 0.03 & 0.04 & 0.32 & $<0.01$ & 0.22 & 0.04 \\
\hline Distance & 0.10 & 0.20 & 0.65 & $<0.01$ & 0.08 & 0.30 \\
\hline Slurry $\times$ distance & $<0.01$ & $<0.01$ & 0.65 & $<0.01$ & 0.49 & $<0.01$ \\
\hline
\end{tabular}

All values are in $\mathrm{mg} \mathrm{kg}^{-1}$. Within the same column, values followed by different letters are significantly different at the 0.05 probability level based on the LSD test. Standard deviation values are shown in parentheses

\subsection{Residue Analyses}

Analysis of variance indicated that neither slurry application nor distance significantly affected measurements of chloride, iron, manganese, nitrogen, or potassium (Tables 9 and 10). However, interaction effects between slurry application and distance were found for boron, calcium, copper, magnesium, phosphorus, sulfur, and zinc, and changes in these constituent quantities following slurry application are presented in Tables 7 and 8 .

No significant differences in concentrations of phosphorus were found among sampling locations on the nonslurry treatments (Fig. 7). The phosphorus concentration of $3.01 \mathrm{~g} \mathrm{~kg}^{-1}$ measured at the $2.44 \mathrm{~m}$ distance on the slurry treatment was significantly greater than values obtained at the other sampling sites. It was determined that $26.3 \mathrm{~g}$ of

Table 10 Effects of slurry application and distance on chemical characteristics of residue

\begin{tabular}{|c|c|c|c|c|c|c|}
\hline & Manganese & Nitrogen & Phosphorus & Potassium & Sulfur & Zinc \\
\hline \multicolumn{7}{|l|}{ Slurry application } \\
\hline No slurry & $167(95)$ & 9990 (2060) & $1110(201)$ & $2090(590)$ & 938 (174) & $32.4 \mathrm{~b}(6.5)$ \\
\hline Slurry & $185(66)$ & $10,400(1820)$ & $1340(827)$ & $2270(1640)$ & $1070(246)$ & $64.6 \mathrm{a}(39.4)$ \\
\hline \multicolumn{7}{|l|}{ Distance (m) } \\
\hline 2.44 & $131(41)$ & $11,100(2840)$ & 2030a (1300) & $2500(2230)$ & 1160a (408) & $88.2 \mathrm{a}(70.4)$ \\
\hline 5.18 & $181(80)$ & $9940(1380)$ & $1140 \mathrm{~b}(210)$ & $2630(1450)$ & 980b (156) & $43.7 b(14.9)$ \\
\hline 7.92 & $170(59)$ & $10,200(1520)$ & 1110b (190) & $2290(585)$ & $980 \mathrm{~b}(161)$ & $40.5 b(10.1)$ \\
\hline 11.0 & $175(89)$ & $9680(2090)$ & 1040b (210) & $2280(650)$ & $940 \mathrm{~b}(163)$ & $40.6 b(9.4)$ \\
\hline 14.0 & $175(47)$ & $9830(1690)$ & $1050 \mathrm{~b}(230)$ & $2290(1390)$ & $970 b(160)$ & $41.1 \mathrm{~b}(10.5)$ \\
\hline 17.1 & $194(73)$ & $10,600(1760)$ & 1120b (178) & $2660(1160)$ & 1020b (172) & $43.9 b(13.3)$ \\
\hline 20.1 & $204(138)$ & $9690(1870)$ & $1070 b(224)$ & $2370(810)$ & $980 \mathrm{~b}(166)$ & $41.6 \mathrm{~b}(12.2)$ \\
\hline \multicolumn{7}{|l|}{ ANOVA $(p>F)$} \\
\hline Slurry & 0.60 & 0.69 & 0.21 & 0.32 & 0.29 & $<0.01$ \\
\hline Distance & 0.22 & 0.13 & $<0.01$ & 0.89 & 0.02 & $<0.01$ \\
\hline Slurry $\times$ distance & 0.76 & 0.26 & $<0.01$ & 0.49 & $<0.01$ & $<0.01$ \\
\hline
\end{tabular}

All values are in $\mathrm{mg} \mathrm{kg}^{-1}$. Within the same column, values followed by different letters are no manure 


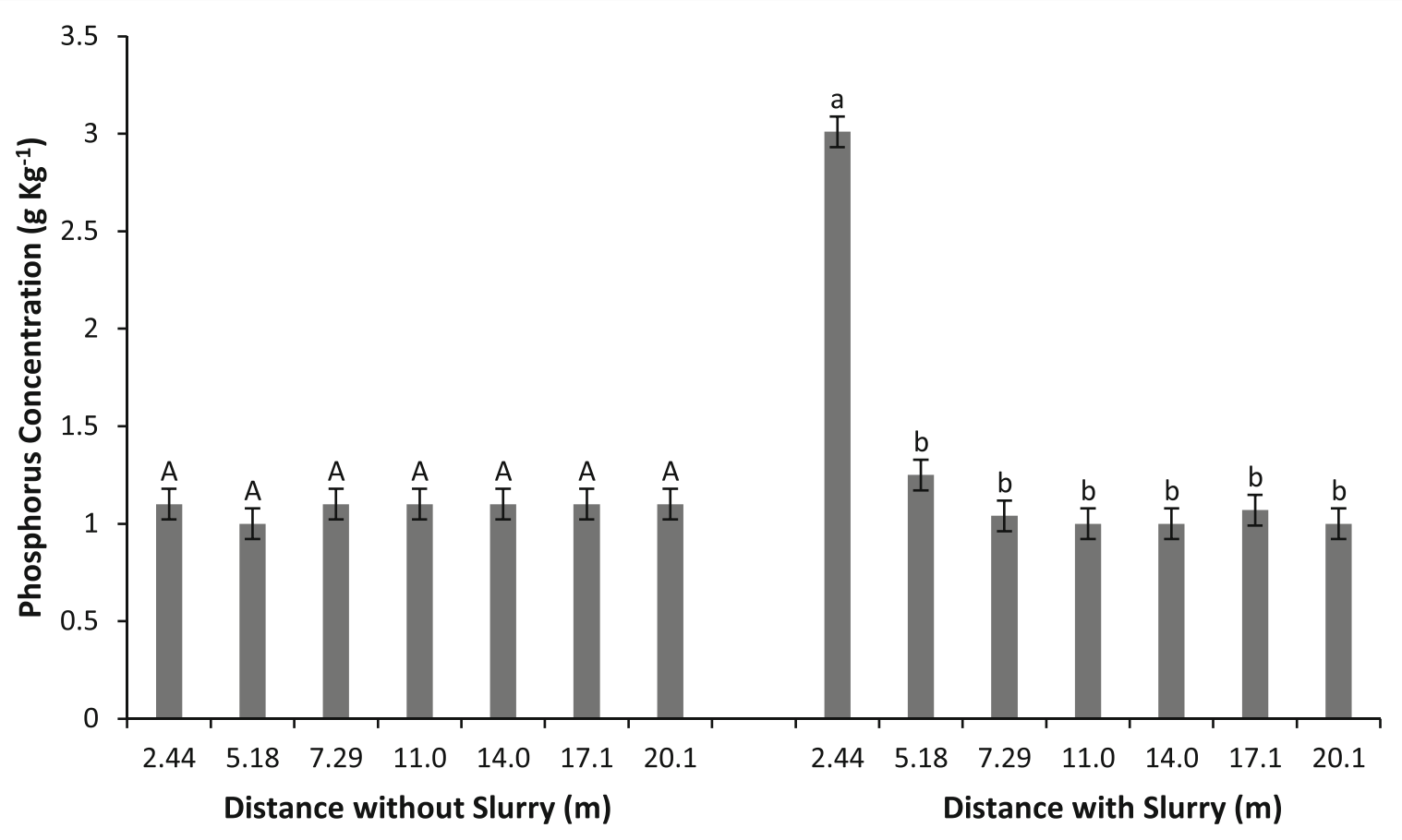

Fig. 7 Phosphorus concentrations of residue as affected by distance for conditions with and without slurry. Vertical bars are standard errors. Concentration values with different letters for

phosphorus was absorbed by residue materials within the $4.9 \mathrm{~m}$ slurry application area (Table 8). No significant changes in phosphorus concentrations were found in the region downslope from the slurry application area. The experimental results found for phosphorus were also characteristic of measurements obtained for copper and sulfur. Cermak et al. (2004) reported that wheat residue adsorbed phosphorus with an increase in sorption generally resulting from greater residue solution/contact time.

Concentrations of zinc were greater on the slurry than the no-slurry treatments at each sampling location (Fig. 8). The $149 \mathrm{mg} \mathrm{kg}^{-1}$ of zinc found within the slurry application area at a distance of $2.44 \mathrm{~m}$ was significantly greater than values found at the other sampling sites. The quantities of zinc adsorbed by crop residue within the slurry application area and downslope region were 1.61 and $0.940 \mathrm{~g}$, respectively (Table 8). Measurements obtained for boron, calcium, and magnesium were also characteristic of results found for zinc. Substantial quantities of boron, calcium, and magnesium were present in both the slurry and simulated rainfall. conditions with or without slurry are significantly different at the 0.05 probability level based on the LSD test

During the 48-h period prior to slurry application, $108 \mathrm{~mm}$ of rainfall was applied to the experimental plots. The residue would have been at a near saturated condition at the time of slurry application. Adsorption of constituents contained in the slurry by the residue would have been larger if slurry had not been applied when the residue materials were at a near saturated condition.

\subsection{Implications for Setback Calculations}

No significant changes in soil concentrations of boron, calcium, copper, iron, magnesium, manganese, potassium, sodium, or sulfur with distance were identified (Tables 4, 5, and 6). Additional quantities of chloride $(5.52 \mathrm{~g})$, nitrate $(12.1 \mathrm{~g})$, and zinc $(0.26 \mathrm{~g})$ were measured in the soil downslope from the slurry application area (Tables 7 and 8). In comparison, the quantities of chloride, nitrate, and zinc transported in runoff from the 4.9-23.2 $\mathrm{m}$ distance were 7.04, 44.8, and $0.00 \mathrm{~g}$, respectively.

Concentrations of chloride, iron, manganese, nitrogen, and potassium within the residue materials did not change significantly with distance following slurry 


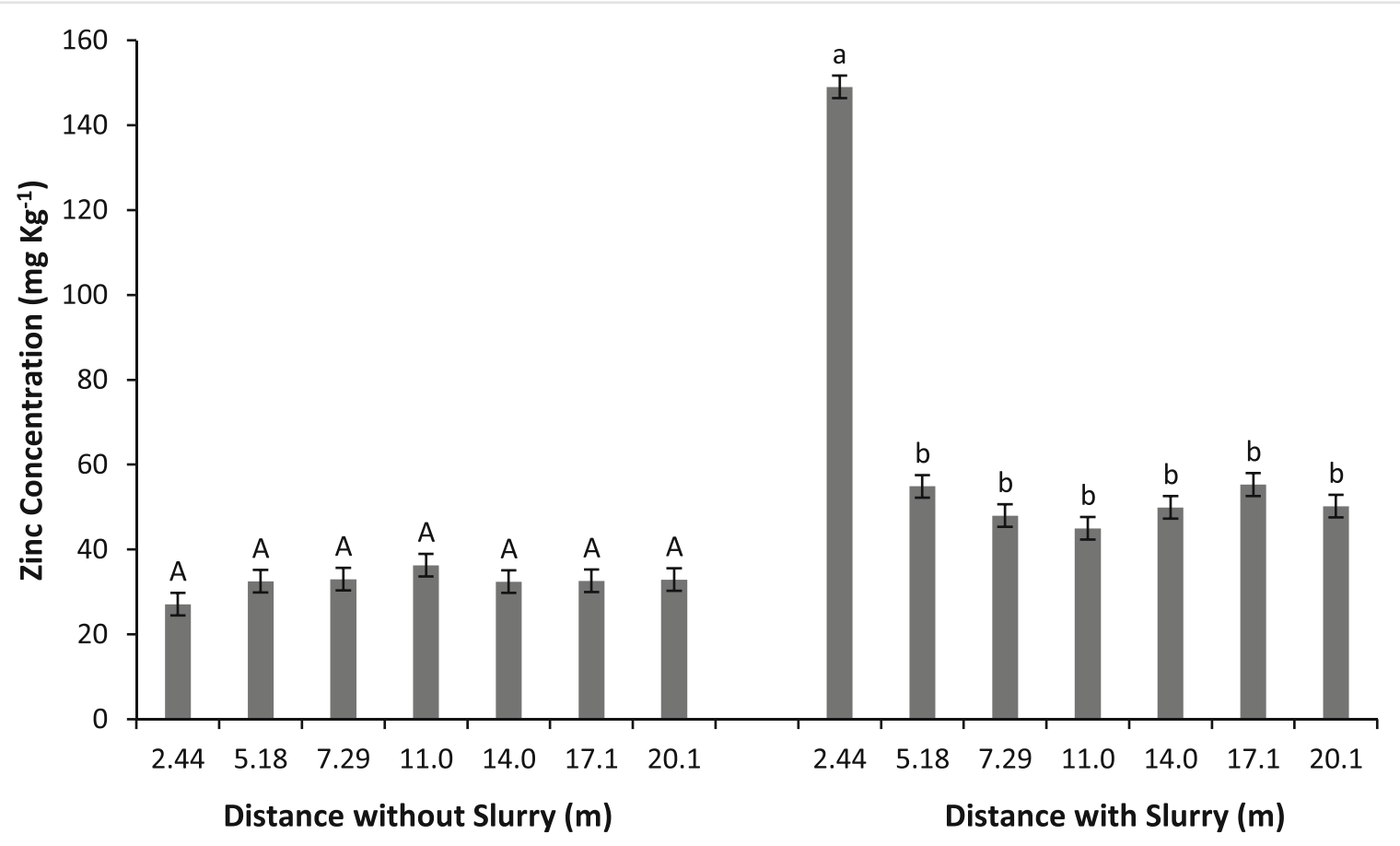

Fig. 8 Zinc concentrations of residue as affected by distance for conditions with and without slurry. Vertical bars are standard errors. Concentration values with different letters for conditions

application (Tables 9 and 10). Additional quantities of boron $(0.126 \mathrm{~g})$, calcium $(130 \mathrm{~g})$, copper $(0.131 \mathrm{~g})$, magnesium (39.8 g), sulfur (4.24 g), and zinc (0.94 g) were found within residue materials located downslope from the area where slurry was applied (Tables 7 and 8). The quantities of boron, calcium, copper, magnesium, sulfur, and zinc transported in runoff from the 4.9$23.2 \mathrm{~m}$ downslope distance were $0.215,320,0.038$, 71.6, 57.7, and $0.00 \mathrm{~g}$, respectively.

Dilution has been reported to be responsible for the reduction in pollutant concentrations within vegetative buffer areas (Bingham et al. 1980; Overcash et al. 1981; Chaubey et al. 1994, 1995; Edwards et al. 1996; Schmitt et al. 1999). In this investigation, significant quantities of constituents were measured in runoff, soil, and residue located downslope from the swine application area. In general, the quantity of constituents transported downslope followed the trend: runoff $>$ soil $>$ residue (Tables 7 and 8).

This study was conducted to measure the changes in selected chemical constituents in runoff, soil, and crop residue within a 48 -h period following swine slurry with or without slurry are significantly different at the 0.05 probability level based on the LSD test

application. Additional quantities of chemical constituents would be transported in runoff during subsequent rainfall events. The largest quantities of dissolved phosphorus in runoff have been measured during the first rainfall events occurring following slurry application (Gilley et al. 2007; Schuster et al. 2017).

\section{Conclusions}

Significant increases in concentrations of chloride, nitrate, and zinc were measured in soil samples collected both within and downslope of the slurry application area. Residue materials both within and downslope from the slurry application area contained significantly increased concentrations of boron, calcium, copper, magnesium, sulfur, and zinc. The largest increases in constituent concentrations of both soil and residue occurred within the slurry application area. Contributions from runoff, soil, and residue should all be considered when estimating downslope transport of constituents contained in swine slurry. The downslope transport of constituents contained in swine slurry followed the trend: runoff> soil > residue. 
Funding Information Funding was provided by the National Pork Checkoff.

\section{References}

Bingham, S. C., Westerman, P. W., \& Overcash, M. R. (1980). Effect of grass buffer zone length in reducing the pollution from land application areas. Transactions of ASAE, 23(2), 330-335 342.

Bray, R. N., \& Kurtz, T. (1945). Determination of total, organic, and available forms of phosphorus in soils. Soil Science, 59(1), 39-45.

Buchanan, B., Auerbach, D. A., Knighton, J., Evensen, D., Fuka, D. R., Easton, Z., Wieczorek, M., Archibald, J. A., McWilliams, B., \& Walter, T. (2018). Estimating dominant runoff modes across the conterminous United States. Hydrological Processes, 26(32), 3881-3890.

Cermak, J. D., Gilley, J. E., Eghball, B., \& Wienhold, B. J. (2004). Leaching and sorption of nitrogen and phosphorus by crop residue. Transactions of ASAE, 47(1), 113-118.

Chaubey, I., Edwards, D. R., Daniel, T. C., Moore, P. A., \& Nichols, D. J. (1994). Effectiveness of vegetative filter strips in retaining surface-applied swine manure constituents. Transactions of ASAE, 37(3), 845-850.

Chaubey, I., Edwards, D. R., Daniel, T. C., Moore, P. A., \& Nichols, D. J. (1995). Effectiveness of vegetative filter strips in controlling losses of surface-applied poultry litter constituents. Transactions of ASAE, 38(6), 1687-1692.

Choudhary, M., Bailey, L. D., \& Grant, C. A. (1996). Review of the use of swine manure in crop production: Effects on yield and composition on soil and water quality. Waste Management \& Research, 14, 581-595.

Edwards, D. R., Daniel, T. C., \& Moore, P. A. (1996). Vegetative filter strip design for grassed areas treated with animal manures. Applied Engineering in Agriculture, 12(1), 31-38.

EPA. (2012). CAFO final rule 412.4: Best management practices (BMPS) for land application of manure, litter, and process wastewater. Washington, DC: U.S. Environmental Protection Agency.

Evans, S. D., Goodrich, P. R., Munter, R. C., \& Smith, R. E. (1977). Effects of solid and liquid beef manure and liquid hog manure on soil characteristics and on growth, yield, and composition of corn. Journal of Environmental Quality, 6(4), 361-368.

Gilbertson, C. B., Norstadt, F. A., Mathers, A. C., Holt, R. F., Shuyler, L. R., Barnett, A. P., et al. (1979). Animal waste utilization on cropland and pastureland: A manual evaluating agronomic and environmental effects. Utilization research report no. 6. Washington, DC: USDA.

Gilley, J. E., Eghball, B., \& Marx, D. B. (2007). Nutrient concentrations of runoff during the year following manure application. Transactions of ASAE, 50(6), 1987-1999.

Gilley, J. E., Eghball, B., \& Marx, D. B. (2009). Adsorption and desorption of phosphorus and nitrogen by immersed stalks. Transactions of ASAE, 52(2), 429-436.

Gilley, J. E., Eghball, B., \& Marx, D. B. (2017). Setback distance requirements for removal of swine slurry constituents in runoff. Transactions of ASAE, 60(6), 1885-1894.
Hill, G. M., \& Spears, J. W. (2001). Trace and ultratrace elements in swine nutrition. In A. J. Lewis \& L. L. Southern (Eds.), Swine nutrition. Boca Raton: CRC Press.

Kettler, T. A., Doran, J. W., \& Gilbert, T. L. (2001). Simplified method for soil particle-size determination to accompany soil-quality analyses. Soil Science Society of America Journal, 65(3), 849-852.

King, L. D., Westerman, P. W., Cummings, G. A., Overcash, M. R., \& Burns, J. C. (1985). Swine lagoon effluent applied to 'coastal' bermudagrass: II. Effects on soil. Journal of Environmental Quality, 14(1), 14-21.

King, L. D., Burns, J. C., \& Westerman, P. W. (1990). Long-term swine lagoon effluent applications on 'coastal' bermudagrass: II. Effect on nutrient accumulation in soil. Journal of Environmental Quality, 19(4), 756-760.

Kleinman, P. J. A., \& Sharpley, A. N. (2003). Effect of broadcast manure on runoff phosphorus concentrations over successive rainfall events. Journal of Environmental Quality, 32(3), 1072-1081.

Klute, A. (1986). Part 1. Physical and mineralogical methods. In Methods of Soil Analyses. Madison: Soil Sci. Soc. Amer.

Lozier, T. M., Macrae, M. L., Brunke, R., \& Van Eerd, L. L. (2017). Release of phosphorus from crop residue and cover crops over the non-growing season in a cool temperate region. Agricultural Water Management, 189(1), 39-51.

McLaughlin, M. R., Brooks, J. P., Adeli, A., \& Read, J. R. (2010). Comparison of selected nutrients and bacteria from common contiguous soils inside and outside swine lagoon effluent spray fields after long-term use. Journal of Environmental Quality, 39(5), 1829-1840.

Murphy, J., \& Riley, J. P. (1962). A modified single solution method for the determination of phosphate in natural waters. Anal. Chimica Acta, 27, 31-36.

Nelson, E. W., \& Sommers, L. E. (1996). Total carbon, organic carbon, and organic matter. In D. L. Sparks (Ed.), Methods of soil analysis: Chemical methods. Part 3. Madison: Soil Sci. Soc. Am.

Novak, J. M., Watts, D. W., \& Stone, K. C. (2004). Copper and zinc accumulation, profile distribution, and crop removal in coastal plain soils receiving long-term, intensive applications of swine manure. Transactions of ASAE, 47(5), 1513-1522.

Overcash, M. R., Bingham, S. C., \& Westerman, P. W. (1981). Predicting runoff pollutant reduction in buffer zones adjacent to land treatment sites. Transactions of ASAE, 24(2), 430 435.

NRC. (1998). Nutrient requirements of swine (10th ed.). Washington, DC: National Academy Press.

Patience, J. F., \& Zijlstra, R. T. (2001). Sodium, potassium, chloride, magnesium and sulfur in swine nutrition. In A. J. Lewis \& L. L. Southern (Eds.), Swine nutrition. Boca Raton, FL: CRC Press.

Reddy, K. R., Overcash, M. R., Khaleel, R., \& Westerman, P. W. (1980). Phosphorus adsorption desorption characteristics of two soils utilized for disposal of animal waste. Journal of Environmental Quality, 9(1), 86-92.

Richards, R. R., Zhang, H., Schroder, J. L., Hattey, J. A., Raun, W. R., \& Payton, M. E. (2011). Micronutrient availability as affected by the long-term application of phosphorus fertilizer and organic amendments. Soil Science Society of America Journal, 75(3), 927-939. 
SAS Institute. (2011). SAS/STAT User's Guide. Version 9.3 (Vol. 1, 4th ed.). Cary, NC: SAS Institute.

Schlegel, A. J., Assefa, Y., Bond, H. D., Wetter, S. M., \& Stone, L. R. (2015). Soil physicochemical properties after 10 years of animal waste application. Soil Science Society of America Journal, 79(3), 711-719.

Schmitt, T. P., Dosskey, M. G., \& Hoagland, K. D. (1999). Filter strip performance and processes for different vegetation, widths, and contaminants. Journal of Environmental Quality, 28(5), 1479-1489.

Schreiber, J. D. (1985). Leaching of nitrogen, phosphorus, and organic carbon from wheat straw residues: II. Loading rate. Journal of Environmental Quality, 14(2), 256-260.

Schreiber, J. D., \& McDowell, L. L. (1985). Leaching of nitrogen, phosphorus, and organic carbon from wheat straw residues: I. Rainfall intensity. Journal of Environmental Quality, 14(2), 251-256.

Schulz, E. F., \& Yevjevich, V. (1970). Experimental investigation of small watershed floods. Department of Civil Engineering, Report No. CER 69-70.ERS VY 38. Fort Collins, CO: Colorado State University.

Schuster, N. R., Bartelt-Hunt, S. L., Durso, L. M., Gilley, J. E., Li, X., Marx, D. B., Schmidt, A. M., \& Snow, D. D. (2017). Runoff water quality characteristics following swine slurry application under broadcast and injected conditions. Transactions of ASAE, 60(1), 53-66.

Smith, D. R., Owens, P. R., Leytem, A. B., \& Warnemuende, E. A. (2007). Nutrient losses of manure and fertilizer applications as impacted by time to first runoff event. Environmental Pollution, 147, 131-137.

Sutton, A. L., Nelson, D. W., Mayrose, V. B., \& Nye, J. C. (1978). Effects of liquid swine waste applications on corn yield and soil chemical composition. Journal of Environmental Quality, 7(3), 325-333.

Sutton, A. L., Nelson, D. W., Hoff, J. D., \& Mayrose, V. B. (1982). Effects of injection and surface applications of liquid swine manure on corn yield and soil composition. Journal of Environmental Quality, 11(3), 468-472.

Sutton, A. L., Nelson, D. W., Mayrose, V. B., \& Nye, J. C. (1984). Effects of varying salt levels in liquid swine manure on soil composition and corn yield. Journal of Environmental Quality, 13(1), 49-59.

Westerman, P. W., King, L. D., Burns, J. C., Cummings, G. A., \& Chau, M. R. (1987). Swine manure and lagoon effluent applied to temperate forage mixture: II. Rainfall runoff and soil chemical properties. Journal of Environmental Quality, 16(2), 106-112.

Wienhold, B. J. (2005). Changes in soil attributes following low phosphorus swine slurry application to no-tillage sorghum. Soil Science Society of America Journal, 69(1), 206-214.

Publisher's Note Springer Nature remains neutral with regard to jurisdictional claims in published maps and institutional affiliations. 